\title{
SISTEM PENDUKUNG KEPUTUSAN DATA ALUMNI SARJANA KOMPUTER MENGGUNAKAN METODE INFERENSI MAMDANI BERBASIS MATLAB
}

\author{
Yustria Handika Siregar \\ Program Studi Teknik Informatika Fakultas Teknik Universitas Asahan \\ Jalan Jendral Ahmad Yani, Asahan, Sumatera Utara - Indonesia
}

yustria.siregar@gmail.com

\begin{abstract}
Abstrak - Pesatnya perkembangan teknologi informasi ini memicu banyak kalangan untuk mencari alternatif pemecahan masalah di bidang teknologi sistem informasi. Sebagai kasus keputusan untuk pemilihan pekerjaan, jabatan atau karir tertentu yang merupakan suatu rentetan akibat dari keputusankeputusan yang dibuat individu pada tahap-tahap kehidupannya di masa lalu. Penggunaan sistem pendukung keputusan ini dapat memberikan kemudahan kepada alumni dalam menentukan pilihan pekerjaan sesuai dengan kemampuan atau nilai dari data alumni. Permasalahan yang akan dibahas dalam penelitian ini adalah bagaimana memilih kriteria pekerjaan yang tepat menggunakan metode Mamdani.
\end{abstract}

Kata Kunci - Sistem Pendukung Keputusan, Mamdani, Data Alumni

\section{PENDAHULUAN}

Dengan berkembangnya teknologi informasi secara tidak langsung juga mempengaruhi kualitas dari informasi yang diberikan. Perkembangan ilmu pengetahuan dan teknologi memicu banyak kalangan untuk mencari alternatif pemecahan masalah di bidang teknologi sistem informasi. Penggunaan aplikasi perangkat lunak sebagai alat bantu penyelesaian pekerjaan kian marak dan berkembang di segala bidang dan juga dapat disesuaikan dengan keinginan pemakainya.

Pengelolaan data alumni di Program Studi Teknik Informatika Universitas Asahan belum terlalu diperhatikan walaupun sudah dilakukan secara komputerisasi. Keputusan untuk pemilihan pekerjaan, jabatan atau karir tertentu merupakan suatu rentetan akibat dari keputusan-keputusan yang dibuat individu pada tahap-tahap kehidupannya di masa lalu.
Perkembangan pekerjaan itu diorientasikan dari keputusan mengenai pendidikan, kerja dan kehidupannya.

Pemilihan pekerjaan bagi mahasiswa pada sebuah perusahaan, instansi pemerintah atau swasta, merupakan sebuah persoalan yang membutuhkan penanganan yang baik. Pemilihan pekerjaan adalah persoalan yang komplek karena beberapa hal berikut:

1. Tingkat pengangguran yang tinggi sehingga persaingan untuk mendapatkan pekerjaan semakin ketat.

2. Lowongan atau peluang kerja, baik di sebuah lembaga swasta maupun lembaga negeri yang relatif terbatas.

3. Tuntutan hidup yang semakin berat dan meningkat. 
4. Keterbatasan wawasan mahasiswa tentang dunia kerja sehingga peminatan dan kemampuan kerap tidak sesuai.

5. Memilih dan merencanakan karir merupakan salah satu tugas perkembangan pada masa remaja. Hakikat perkembangan ini adalah memilih suatu pekerjaan yang sesuai dengan kemampuannya dan mempersiapkan diri memiliki pengetahuan dan keterampilan untuk memasuki pekerjaan tersebut. Dasar psikologis studi tentang minat remaja, menunjukkan bahwa perencanaan dan persiapan pekerjaan merupakan minatnya yang pokok, baik remaja pria maupun wanita.

Sistem pendukung keputusan pemilihan pekerjaan dapat membantu alumni mahasiswa yang ingin memilih pekerjaan yang tepat sesuai dengan kemampuannya, sehingga bisa mempersiapkan diri untuk pekerjaan yang diinginkan atau yang disarankan oleh sistem.

\section{A. Sistem Pendukung Keputusan}

Keputusan adalah suatu pengakhiran dari pada proses pemikiran tentang suatu masalah atau problema untuk menjawab pertanyaan apa yang harus diperbuat guna mengatasi masalah tersebut, dengan menjatuhkan pilihan pada suatu alternatif (Hasan, 2002). Pada dasarnya pengambilan keputusan merupakan suatu bentuk pemilihan dari berbagai alternatif tindakan yang mungkin dipilih, yang prosesnya melalui mekanisme tertentu, dengan harapan akan menghasilkan sebuah keputusan yang terbaik. Penyusunan sebuah model keputusan merupakan suatu cara untuk mengembangkan hubungan-hubungan logis yang mendasari persoalan keputusan ke dalam suatu bentuk model matematis, yang mencerminkan hubungan di antara faktor faktor yang terlibat (Herlan Sutisna dan Noor Cholis Basjaruddin, 2015). Model yang menggambarkan proses pengambilan keputusan terdiri dari empat fase, yaitu:

1. Penelusuran (Intelligence)

Tahap ini merupakan tahap pendefinisian masalah serta identifikasi informasi yang dibutuhkan yang berkaitan dengan persoalan yang dihadapi serta keputusan yang akan diambil.

2. Perancangan (Design)

Tahap ini merupakan suatu proses untuk merepresentasikan model sistem yangakan dibangun berdasarkan pada asumsi yang telah ditetapkan. Dalam tahap ini, suatu model dari masalah dibuat, diuji, dan divalidasi.

3. Pemilihan (Choice)

Tahap ini merupakan suatu proses melakukan pengujian dan memilih keputusan terbaik berdasarkan kriteria tertentu yang telah ditentukan dan mengarah kepada tujuan yang akan dicapai.

4. Implementasi (Implementation)

Tahap ini merupakan tahap pelaksanaan dari keputusan yang telah diambil. Pada tahap ini perlu disusun serangkaian tindakan yang terencana, sehingga hasil keputusan dapat dipantau dan disesuaikan apabila diperlukan perbaikan perbaikan.

\section{B. Logika Fuzzy}

Logika fuzzy (fuzzy logic) merupakan cabang dari sistem kecerdasan buatan (artificial intelegent) yang memungkinkan kemampuan manusia dalam berfikir dibuat dalam bentuk algoritma yang kemudian dijalankan oleh mesin (komputer). Algoritma ini digunakan dalam berbagai aplikasi pemrosesan data yang tidak dapat direpresentasikan dalam bentuk biner. Fuzzy logic menginterpretasikan statemen yang samar menjadi sebuah pengertian yang logis (Herlan Sutisna dan Noor Cholis Basjaruddin, 2015). 
Fuzzy dipresentasikan bukan sebagai metodologi kontrol, namun sebagai suatu cara pemrosesan data yang memperbolehkan anggota himpunan parsial daripada anggota himpunan kosong atau non-anggota. Pendekatan ini pada teori himpunan tidak diaplikasikan untuk mengontrol sistem sampai tahuan 70-an karena kurangnya kemampuan komputer mini pada saat itu (Kusrini, 2008). Pelopor aplikasi fuzzy set dalam bidang kontrol yang merupakan aplikasi pertama dan utama dari fuzzy set adalah Prof. Ebrahim Mamdani dan kawan-kawan dari Queen Mary College London. Penerapan fuzzy secara nyata di industri banyak dipelopori para ahli dari Jepang, misalnya Prof. Mamdani dari Tokyo Institute of Technology, Prof. Yamakawa dari KyusuInstitute of Technology, Togay dan Watanabe dari Bell Telephone Labs.

Metode logika fuzzy memiliki tiga tahapan proses fuzzifikasi, inferensi dan defuzzifikasi. Logika fuzzy adalah nilai yang memiliki samar (fuzzyness) antara benar dan salah. Secara teori, logika fuzzy bisa bernilai benar dan salah pada saat yang sama tapi berapa banyak kebenaran dan kesalahan suatu nilai tergantung pada berapa banyak berat badan keanggotaannya. Secara teori, logika fuzzy, himpunan fuzzy dikenal (fuzzy set) yang merupakan pengelompokan sesuatu berdasarkan variabel bahasa (variabel linguistik) yang dinyatakan dalam nilai fungsi keanggotaan dari nol sampai satu. Pengontrol dengan fuzzy logic mempunyai kelebihan, yaitu dapat mengontrol sistem yang kompleks, non-linier, atau sistem yang sulit direpresentasikan ke dalam bentuk matematis. Selain itu, informasi berupa pengetahuan dan pengalaman mempunyai peranan penting dalam mengenali perilaku sistem di dunia nyata. Fuzzy logic juga memiliki himpunan fuzzy yang mana pada dasarnya, teori himpunan fuzzy merupakan perluasan dari teori himpunan klasik. Dimana dengan fuzzy logic, hasil yang keluar tidak akan selalu konstan dengan input yang ada. Cara kerja fuzzy logic secara garis besar terdiri dari input, proses dan output. Fuzzy logic merupakan suatu teori himpunan logika yang dikembangkan untuk mengatasi konsep nilai yang terdapat diantara kebenaran (true) dan kesalahan (false). Dengan menggunakan fuzzy logic nilai yang dihasilkan bukan hanya ya (1) atau tidak (0) tetapi seluruh kemungkinan diantara 0 dan 1. Ada beberapa hal yang perlu diketahui dalam memahami sistem fuzzy antara lain (Agusman, Wijaya dan Ingo, 2009) :

1. Variabel fuzzy merupakan variabel yang akan dibahas dalam suatu sistem fuzzy.

2. Himpunan fuzzy merupakan suatu grup yang mewakili suatu kondisi atau keadaan tertentu dalam suatu variabel fuzzy.

3. Semesta pembicaraan merupakan keseluruhan nilai yang diperbolehkan untuk dioperasikan dalam suatu variabel fuzzy.

4. Domain adalah keseluruhan nilai yang diijinkan dalam semesta pembicaraan dan boleh dioperasikan dalam suatu himpunan fuzzy.

\section{Metode Mamdani}

Dua metode defuzzyfikasi yang umum digunakan adalah (Herlan Sutisna dan Noor Cholis Basjaruddin, 2015) :

1. Maksimum of Mean (MOM)

$$
v_{0}=\sum_{j=1}^{j} \frac{v_{j}}{J}
$$

Dimana :

$$
\begin{array}{ll}
v_{0} & : \text { Nilai keluaran } \\
J & : \text { Jumlah harga maksimum } \\
v_{j} & : \text { Nilai keluaran maksimum ke-j } \\
\mu_{v}(v) & : \text { Derajat keanggotaan elemen- }
\end{array}
$$
elemen pada fuzzy setv

$v \quad:$ Semesta pembicaraan 


\section{Centre of Area (COA)}

Metode ini didefinisikan sebagai :

$$
v_{0}=\frac{\sum_{j=1}^{j} v_{k} \mu_{k}\left(v_{k}\right)}{\sum_{k=1}^{m} \mu_{v}\left(v_{k}\right)}
$$

Dimana :

$$
\begin{array}{ll}
v & : \text { Nilai keluaran } \\
m & : \text { Tingkat kuantisasi } \\
v_{0} & : \text { Elemen ke- } k \\
\mu_{v}\left(v_{k}\right) & : \text { Derajat keanggotaan elemen- }
\end{array}
$$
elemen pada fuzzy setv

$$
v \quad: \text { Semesta pembicaraan }
$$

\section{MatLab}

Matlab (Matrix Laboratory) adalah sebuah bahasa pemrograman tingkat tinggi berbasis matrix untuk komputasi teknik. Program ini merupakan produk komersial dari perusahaan Mathworks, Inc yang dikembangkan menggunakan Bahasa $\mathrm{C}++$ dan Assembler. Di dalam Matlab terdapat banyak terdapat banyak toolbox, yaitu kumpulan fungsi komprehensif yang digunakan untuk menyelesaikan kelas problem dan memungkinkan kita mempelajari dan mengaplikasikan teknologi tertentu (Herlan Sutisna dan Noor Cholis Basjaruddin, 2015). Berbagai toolbox dalam Matlab antara lain signal processing, control system, neural network, fuzzy logic, wavelets, simulation, statistics, optimization, bioinformatics, genetic algorithm dan lain-lain (Santosa, 2007). Matlab banyak digunakan (Arhami dan Desiani, 2005) pada :

1. Matematika dan komputasi.

2. Pengembangan dan algoritma.

3. Pemrograman modelling, simulasi dan prototype.

4. Analisis dan statistik.

5. Pengembangan aplikasi teknik.

Pada penelitian ini menggunakan bantuan matlab untuk simulasi grafik dan rule karena pada Matlab menyediakan perkakas untuk membuat Fuzzy
Inference System (FIS), yaitu Fuzzy Logic Toolbox yang di dalamnya terdapat Graphical User Inferensi (GUI) untuk merancang FIS (Naba, 2009). GUI tersebut adalah:

1. FIS Editor.

2. Membership Function Editor.

3. Rule Editor.

4. Rule Viewer.

5. Surface Editor.

\section{METODE PENELITIAN}

Penelitian ini menggunakan metode Mamdani dalam pelaksanaan awal penelitiannya meliputi pengumpulan data. Penelitian ini disusun sebagai penelitian induktif yakni mencari dan mengumpulkan data yang ada di lapangan dengan tujuan untuk mengetahui data-data mata kuliah di lingkungan tempat penelitian. Hal di atas sudah secara umum dilakukan banyak orang dalam meneliti.

1. Mengumpulkan Data

Kerangka kerja ini dimulai dari mengumpulkan data, yang terdiri dari penelitian perpustakaan (library research), penelitian lapangan (field research), dan penelitian laboratorium (laboratory research).

2. Mengolah Data

Setelah mengumpulkan data di atas selesai selanjutnya dilakukan pengolahan data. Hal ini bertujuan untuk melakukan pengelompokan terhadap data tersebut sehingga akan memudahkan penulis di dalam melakukan langkah berikutnya. Pengolahan data diperlukan untuk melakukan perhitungan pada logika fuzzy.

3. Mengembangkan Sistem Menggunakan Matlab R2010a

Tahap ini membahas tentang perancangan dari model sistem dengan menentukan rancangan input di dalam penentuan 
pemilihan pekerjaan dengan ketentuan sudah ditetapkan berdasarkan data yang ada.

4. Mengimplementasikan Sistem

Tahapan berikutnya yang akan dilakukan di dalam penelitian adalah melakukan implementasi dari sistem yang telah dibangun, yaitu dengan sistem pendukung keputusan dan memberikan informasi mata kuliah yang tepat dengan menggunakan logika fuzzy metode mamdani.

5. Menguji Sistem

Pada tahap pengujian ini dijelaskan tentang bagaimana hasil tahapan proses penentuan mata kuliah pilihan. Tahapan proses tersebut adalah mengambil data mata kuliah dari program studi. Setelah itu, memasukkan data yang telah diperoleh ke dalam sistem pendukung keputusan untuk menentukan mata kuliah pilihan. Sehinga hasil dari sistem pendukung keputusan dapat diterima oleh mahasiswa. Pengujian dilakukan dengan kompleks dan diharapkan dapat diketahui kekurangan-kekurangan dari sistem untuk kemudian diperbaiki sehingga kesalahan dari sistem dapat diminimalisasi atau bahkan dihilangkan. Pengujian sistem ini dilakukan untuk mendapatkan hasil yang akurat.

\section{HASIL DAN PEMBAHASAN}

\section{A. Penentuan Input dan Output}

Untuk menentukan input dan output dapat diperoleh dari semesta pembicaraan.

1. Menentukan Semesta Pembicaraan

Pada objek yang diteliti diperoleh dari Program Studi Teknik Informatika Fakultas Teknik UNA diperoleh pada pengumpulan data.
Tabel 3.1 Semesta Pembicaraan

\begin{tabular}{|c|c|c|c|}
\hline Variabel & Notasi & $\begin{array}{c}\text { Semesta } \\
\text { Pembicaraan }\end{array}$ & Keterangan \\
\hline $\begin{array}{c}\text { Alternatif } \\
\text { Pekerjaan }\end{array}$ & AP & {$[0-100]$} & $\begin{array}{c}\text { Jumlah } \\
\text { Nilai }\end{array}$ \\
\hline
\end{tabular}

2. Menentukan Input

Input yang diperoleh terlihat pada tabel 3.2 berikut.

Tabel 3.2 Penentuan Input

\begin{tabular}{|c|c|c|c|c|}
\hline Fungsi & Variabel & Notasi & $\begin{array}{c}\text { Semesta } \\
\text { Pembicaraan }\end{array}$ & Ket. \\
\hline \multirow{3}{*}{ Input } & $\begin{array}{l}\text { Sistem Basis } \\
\text { Data }\end{array}$ & $\mathrm{C} 1$ & {$[0-100]$} & $\begin{array}{c}\text { Jumlah } \\
\text { Nilai }\end{array}$ \\
\hline & $\begin{array}{l}\text { Sistem } \\
\text { Informasi }\end{array}$ & $\mathrm{C} 2$ & {$[0-100]$} & $\begin{array}{c}\text { Jumlah } \\
\text { Nilai }\end{array}$ \\
\hline & $\begin{array}{l}\text { Pemrograman } \\
\text { Visual }\end{array}$ & C3 & {$[0-100]$} & $\begin{array}{r}\text { Jumlah } \\
\text { Nilai }\end{array}$ \\
\hline
\end{tabular}

3. Menentukan Output

Untuk menentukan output diperoleh dari masing-masing input. Output yang diperoleh terlihat pada tabel 3.3 berikut.

Tabel 3.3 Penentuan Output

\begin{tabular}{|c|c|c|c|c|}
\hline Fungsi & Variabel & Notasi & $\begin{array}{c}\text { Semesta } \\
\text { Pembicaraan }\end{array}$ & Ket. \\
\hline \multirow[t]{3}{*}{ Output } & $\begin{array}{c}\text { System } \\
\text { Analisyst }\end{array}$ & SA & {$[0-100]$} & $\begin{array}{c}\text { Jumlah } \\
\text { Nilai }\end{array}$ \\
\hline & $\begin{array}{c}\text { Database } \\
\text { Administrator }\end{array}$ & DA & {$[0-100]$} & $\begin{array}{c}\text { Jumlah } \\
\text { Nilai }\end{array}$ \\
\hline & $\begin{array}{l}\text { Aplication } \\
\text { Developer }\end{array}$ & $\mathrm{AD}$ & {$[0-100]$} & $\begin{array}{c}\text { Jumlah } \\
\text { Nilai }\end{array}$ \\
\hline
\end{tabular}

\section{B. Pembentukan Logika Fuzzy Mamdani}

Setelah ditentukan semesta pembicaraan, maka langkah selanjutnya menentukan aturan fuzzy dengan metode mamdani. Untuk mendapatkan nilai output dari pendapatan akhir dengan aturan fuzzy 
mamdani dilakukan dengan pembentukan himpunan fuzzy dan derajat keanggotaannya (fuzzifikasi), penentuan rules, penalaran (inferensi) dan defuzzifikasi (defuzzification).

\section{1) Fuzzyfikasi}

Fuzzifikasi (fuzzification) merupakan proses memetakan nilai ke dalam himpunan fuzzy dan menentukan derajat keanggotaannya di dalam himpunan fuzzy. Himpunan fuzzy dan derajat keanggotaan (member function) yang digunakan pada tiap variabel fuzzy ditentukan berdasarkan data kurikukum.

Tabel 3.4 Himpunan Input Fuzzy

\begin{tabular}{|c|c|c|c|c|}
\hline \multicolumn{2}{|c|}{ Variabel } & \multicolumn{2}{c|}{ Himpunan InputFuzzy } & \multirow{2}{*}{ Domain } \\
\hline Nama & Notasi & Nama & Notasi & \\
\hline \multirow{2}{*}{$\begin{array}{c}\text { Sistem } \\
\text { Basis Data }\end{array}$} & \multirow{2}{*}{$C 1$} & Cukup & $C$ & {$[40-70]$} \\
\cline { 3 - 5 } & & Baik & $B$ & {$[55-85]$} \\
\cline { 3 - 5 } & Sangat Baik & $S$ & {$[70-100]$} \\
\hline \multirow{2}{*}{$\begin{array}{c}\text { Sistem } \\
\text { Informasi }\end{array}$} & \multirow{2}{*}{$C 2$} & Cukup & $C$ & {$[40-70]$} \\
\cline { 3 - 5 } & & Baik & $B$ & {$[55-85]$} \\
\cline { 3 - 5 } & & Sangat Baik & $S$ & {$[70-100]$} \\
\hline \multirow{2}{*}{$\begin{array}{c}\text { Pemrogra } \\
\text { man Visual }\end{array}$} & \multirow{2}{*}{$C 3$} & Cukup & $C$ & {$[40-70]$} \\
\cline { 3 - 5 } & & Baik & $B$ & {$[55-85]$} \\
\cline { 3 - 4 } & & Sangat Baik & $S$ & {$[70-100]$} \\
\hline
\end{tabular}

a. Fungsi Derajat Keanggotaan $(\mu)$ Variabel Input Sistem Basis Data

$$
\begin{aligned}
& \mu_{C}[\mathrm{C} 1] \quad=\left\{\begin{array}{cc}
\frac{(\mathrm{x}-40)}{(55-40)} & ; 40 \leq \mathrm{x} \leq 55 \\
1 & ; \mathrm{x}=55 \\
\frac{(70-\mathrm{x})}{(70-55)} & ; \mathrm{x} \leq 40 \mathrm{x} \leq 70 \\
0 & \text { atau } \mathrm{x} \geq 70
\end{array}\right. \\
& \mu_{B}[\mathrm{C} 2] \quad=\left\{\begin{array}{cc}
\frac{(\mathrm{x}-55)}{(70-55)} & ; 55 \leq \mathrm{x} \leq 70 \\
1 & ; \mathrm{x}=70 \\
\frac{(85-\mathrm{x})}{(85-70)} & ; \mathrm{x} \leq 55 \text { atau } \mathrm{x} \geq 85
\end{array}\right. \\
& \mu_{S}[\mathrm{C} 3]=\left\{\begin{array}{cc}
\frac{(\mathrm{x}-70)}{(85-70)} & ; 70 \leq \mathrm{x} \leq 85 \\
1 & ; \mathrm{x}=85 \\
\frac{(100-\mathrm{x})}{(100-85)} & ; 85 \leq \mathrm{x} \leq 100 \\
0 & ; \mathrm{x} \leq 70 \text { atau } \mathrm{x} \geq 100
\end{array}\right.
\end{aligned}
$$

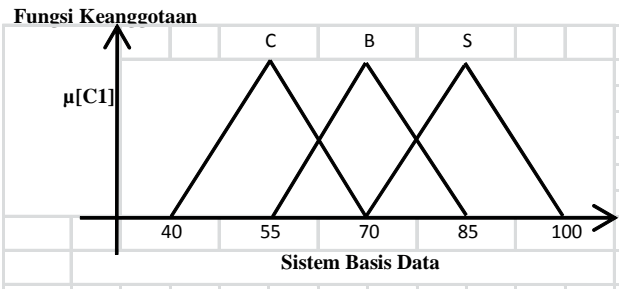

Gambar 3.1 Representasi Fungsi Derajat Keanggotaan

( $\mu$ ) Variabel Input Sistem Basis Data

b. Fungsi Derajat Keanggotaan $(\mu)$ Variabel Input Sistem Informasi

$\mu_{c}[\mathrm{C} 2] \quad=\left\{\begin{array}{cc}\frac{(\mathrm{x}-40)}{(55-40)} & ; 40 \leq \mathrm{x} \leq 55 \\ 1 & ; \mathrm{x}=55 \leq \mathrm{x} \leq 70 \\ \frac{(70-\mathrm{x})}{(70-55)} & ; \mathrm{x} \leq 40 \text { atau } \mathrm{x} \geq 7\end{array}\right.$

$\mu_{B}[\mathrm{C} 2] \quad=\left\{\begin{array}{cc}\frac{(\mathrm{x}-55)}{(70-55)} & ; 55 \leq \mathrm{x} \leq 70 \\ 1 & ; \mathrm{x}=70 \\ \frac{(85-\mathrm{x})}{(85-70)} & ; 70 \leq \mathrm{x} \leq 85 \\ 0 & \mathrm{x} \leq 55 \text { atau } \mathrm{x} \geq 85\end{array}\right.$

$\mu_{S}[\mathrm{C} 2]=\left\{\begin{array}{cc}\frac{(\mathrm{x}-70)}{(85-70)} & ; 70 \leq \mathrm{x} \leq 85 \\ 1 & ; \mathrm{x}=85 \\ \frac{(100-\mathrm{x})}{(100-85)} & ; 85 \leq \mathrm{x} \leq 100 \\ 0 & \mathrm{x} \leq 70 \text { atau } \mathrm{x} \geq 100\end{array}\right.$

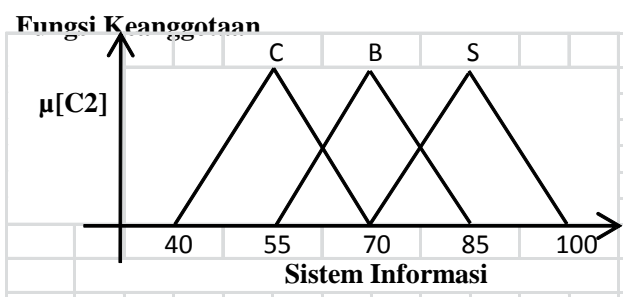

Gambar 3.2 Representasi Fungsi Derajat Keanggotaan

( $\mu$ ) Variabel Input Sistem Informasi 
c. Fungsi Derajat Keanggotaan $(\mu)$ Variabel Input Pemrograman Visual

$$
\begin{aligned}
& \mu_{C}[\mathrm{C} 2] \quad=\left\{\begin{array}{cc}
\frac{(\mathrm{x}-40)}{(55-40)} & ; 40 \leq \mathrm{x} \leq 55 \\
1 & ; \mathrm{x}=55 \\
\frac{(70-\mathrm{x})}{(70-55)} & ; \mathrm{x} \leq 40 \mathrm{x} \leq 70 \\
0 & \text { atau } \mathrm{x} \geq 70
\end{array}\right. \\
& \mu_{B} \text { [C3 } \quad=\left\{\begin{array}{cc}
\frac{(x-55)}{(70-55)} & ; 55 \leq x \leq 70 \\
1 & ; x=70 \\
\frac{(85-x)}{(85-70)} & ; 70 \leq x \leq 85 \\
0 & x \leq 55 \text { atau } x \geq 85
\end{array}\right. \\
& \mu_{S}[\mathrm{C} 3] \quad=\left\{\begin{array}{cc}
\frac{(\mathrm{x}-70)}{(85-70)} & ; 70 \leq \mathrm{x} \leq 85 \\
1 & ; \mathrm{x}=85 \\
\frac{(100-\mathrm{x})}{(100-85)} & ; \mathrm{x} \leq 70 \text { atau } \mathrm{x} \geq 100
\end{array}\right.
\end{aligned}
$$

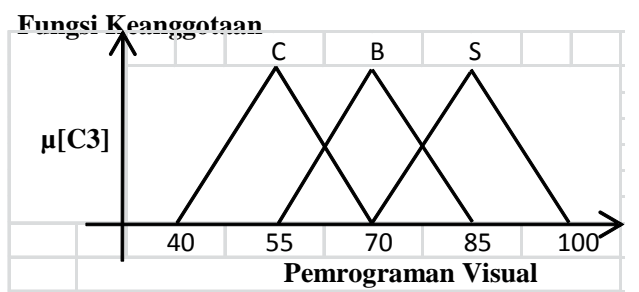

Gambar 3.3 Representasi Fungsi Derajat Keanggotaan

( $\mu$ ) Variabel Input Pemrograman Visual

Tabel 3.5 Output Fuzzy

\begin{tabular}{|c|c|c|c|}
\hline Variabel & Notasi & $\begin{array}{c}\text { Semesta } \\
\text { Pembicaraan }\end{array}$ & Ket. \\
\hline $\begin{array}{c}\text { System } \\
\text { Analisyst }\end{array}$ & SA & {$[0-100]$} & $\begin{array}{c}\text { Jumlah } \\
\text { Nilai }\end{array}$ \\
\hline $\begin{array}{c}\text { Database } \\
\text { Administrator }\end{array}$ & DA & {$[0-100]$} & $\begin{array}{c}\text { Jumlah } \\
\text { Nilai }\end{array}$ \\
\hline $\begin{array}{c}\text { Aplication } \\
\text { Developer }\end{array}$ & AD & {$[0-100]$} & $\begin{array}{c}\text { Jumlah } \\
\text { Nilai }\end{array}$ \\
\hline
\end{tabular}

d. Fungsi Derajat Keanggotaan $(\mu)$ Variabel Output System Analist

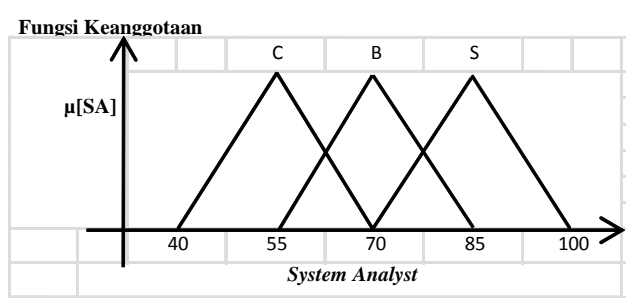

Gambar 3.4 Representasi Fungsi Derajat Keanggotaan

( $\mu$ ) Variabel Output Sistem Cerdas

e. Fungsi Derajat Keanggotaan $(\mu)$ Variabel Output Database Administrator

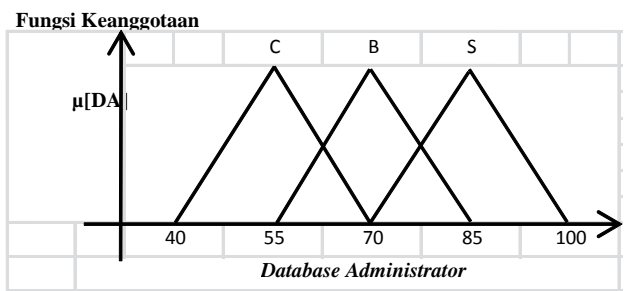

Gambar 3.5 Representasi Fungsi Derajat Keanggotaan

( $\mu$ ) Variabel Output Database Administrator

f. Fungsi Derajat Keanggotaan $(\mu)$ Variabel Output Aplication Developer

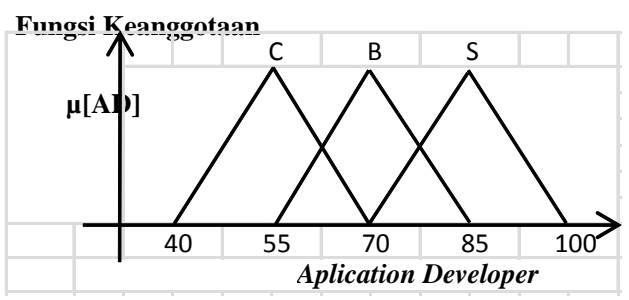

Gambar 3.6 Representasi Fungsi Derajat Keanggotaan

( $\mu$ ) Variabel Output Aplication Developer

\section{2) Pembentukan Rules}

Rules berupa pernyataan kualitatif yang ditulis dalam bentuk IF-THEN, sehingga mudah dimengerti.Rules pada Fuzzy Inference System (FIS) dalam memanajeman bandwidth internet didasari pada jumlah inputan dan jumlah himpunan fuzzy. Penentuan rules didasarkan pada pengujian secara manual dengan memperhitungkan probabilitas kemungkinan yang terjadi dengan kombinasi variabel. 
3) Penentuan Mesin Inferensi

Penentuan mesin inferensi yang digunakan adalah fungsi MIN (nilai terendah) dari rule-rule yang diperolah.

4) Defuzzifikasi

Defuzzifikasi yang digunakan adalah metode centroid.

\section{Pengujian Perhitungan Aplikasi Matlab}

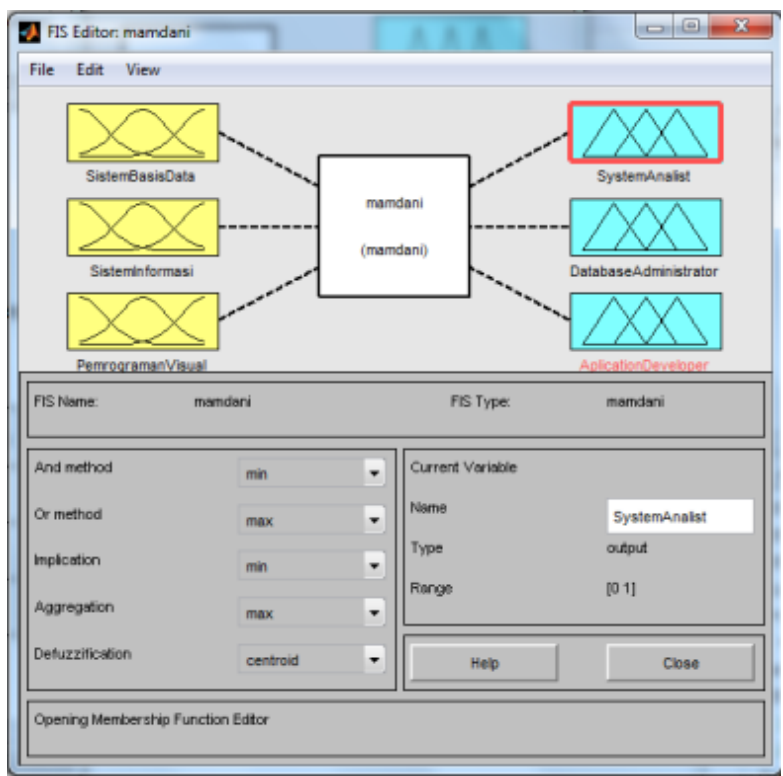

Gambar 3.7 Tampilan Jendela Setting Parameter Input dan Output

1) Fungsi keanggotaan untuk variabel input

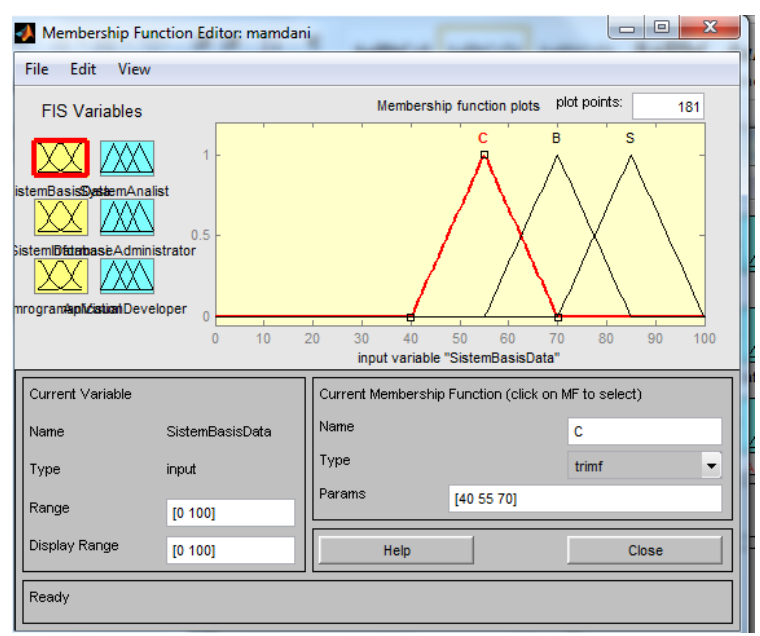

Gambar 3.8 Tampilan Jendela Fungsi Keanggotaan Variabel Input
2) Fungsi keanggotaan untuk variabel output

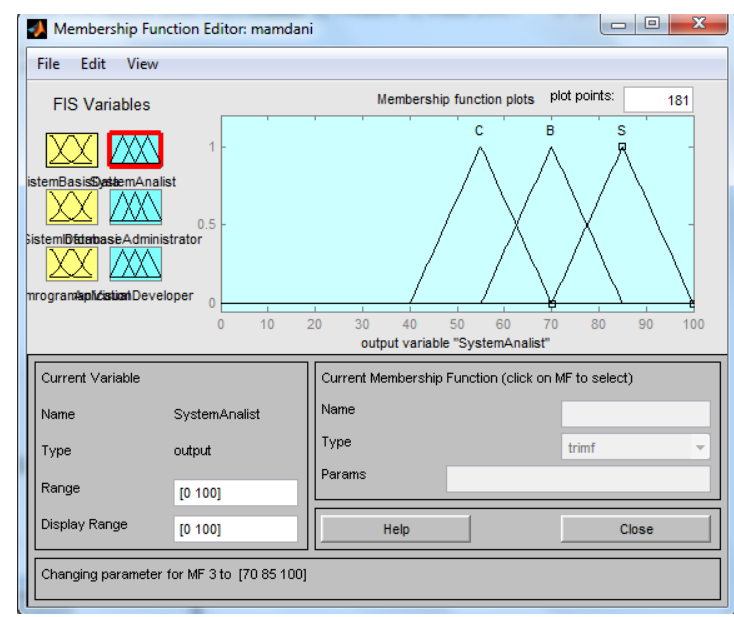

Gambar 3.9 Tampilan Jendela Fungsi Keanggotaan Variabel Output

3) Pembentukan rules

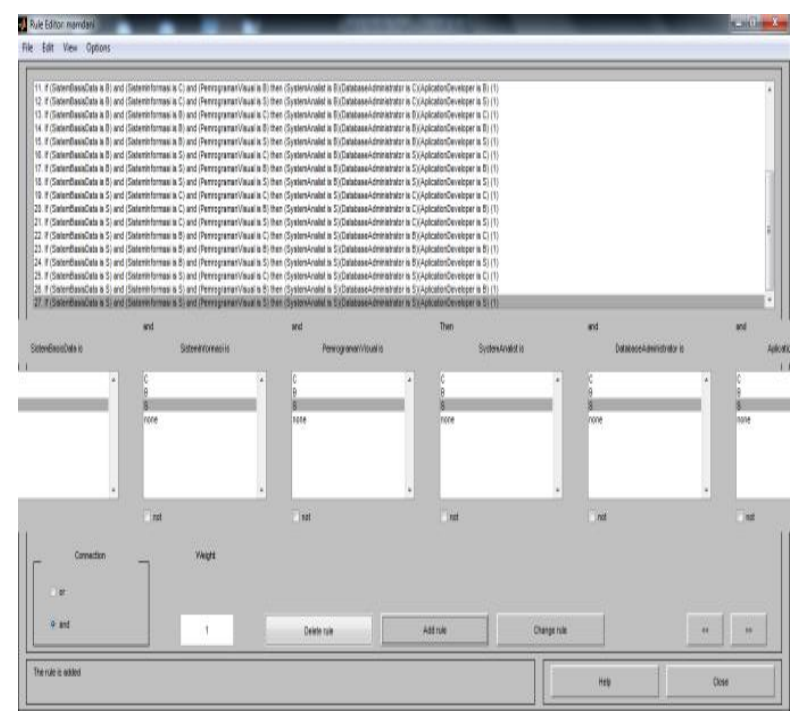

Gambar 3.10 Tampilan Jendela Pembentukan Rule

4) Rule viewer

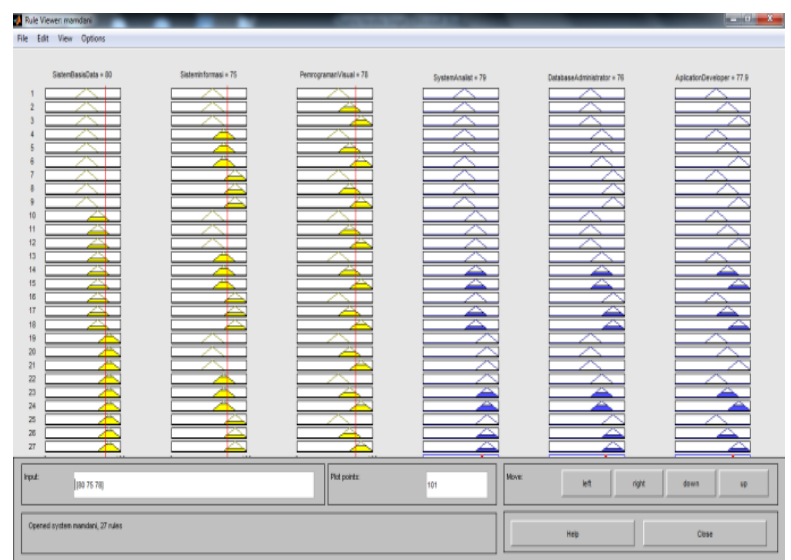

Gambar 3.11 Tampilan Jendela Rule Keseluruhan 
Dari pengujian ini dapat terlihat bahwa dua rule yang diuji menghasilkan output system analisty adalah 79, database administrator adalah 76, aplication developer adalah 77,9. Jika diinputkan masing nilai mata kuliah Sistem Basis Data adalah 80, Sistem Informasi adalah 75 dan Pemrograman Visual 78.

\section{KESIMPULAN}

Berdasarkan penelitian, implementasi dan pengujian, maka dapat diambil kesimpulan sebagai berikut :

1. SPK pekerjaan untuk data alumni ini dapat memberikan kemudahan bagi alumni dalam menentukan pilihan pekerjaan yang sesuai.

2. Memberikan satu bentuk penilaian yang dapat berdampak pada meminimalisir kesalahan dalam memberikan dan menentukan penilaian.

3. Dalam penentuan input fuzzyfication masih berupa sampel dengan 3 mata kuliah. Sehingga output juga merupakan sampel dengan 3 kriteria pekerjaan.

\section{DAFTAR PUSTAKA}

[1]. Hasan, 2002. Pokok-pokok Materi Teori Pengambilan Keputusan. Jakarta : Ghalia Indonesia.

[2]. Herlan Sutisna dan Noor Cholis Basjaruddin, 2015. Sistem Pendukung Keputusan Pemilihan Pekerjaan Menggunakan Metode Fuzzy Mamdani Studi Kasus : Amik Bsi Tasikmalaya. Jurnal Informatika, No. 2, Volume 2.

[3]. Kusrini, 2008. Konsep dan Aplikasi Sistem Pendukung Keputusan. Yogyakarta : Penerbit Andi.

[4]. Agusman, Leo and Wijaya, Shuandy and Ingo, Yakobus, 2009. Aplikasi
Logika Fuzzy Untuk Analisis Tes Kepribadian. Undergraduate Thesis, BINUS.

[5]. Budi Santosa, 2007. Data Mining Teknik Pemanfaatan Data untuk Keperluan Bisnis. Yogyakarta : Graha Ilmu.

[6]. Muhammad Arhami dan Anita Desiani, 2005. Pemrograman Matlab. Yogyakarta : ANDI.

[7]. Agus Naba, 2009. Belajar Cepat Fuzzy Logic Menggunakan Matlab. Yogyakarta : ANDI. 